Article

\title{
Spatial Heterogeneity of Vegetation Structure, Plant N Pools and Soil N Content in Relation to Grassland Management
}

\author{
Juliette M. G. Bloor ${ }^{1, *}$, Antoine Tardif ${ }^{1,2}$ and Julien Pottier ${ }^{1}$ \\ 1 INRAE, Université Clermont Auvergne, Vetagro Sup, UREP, 63000 Clermont-Ferrand, France; \\ antoine.tardif@usherbrooke.ca (A.T.); julien.pottier@inrae.fr (J.P.) \\ 2 UMR CNRS 7058 Ecologie et Dynamique des Systèmes Anthropisés (EDYSAN), Université de Picardie Jules \\ Verne, 33 rue Saint Leu, 80039 Amiens Cedex, France \\ * Correspondence: juliette.bloor@inrae.fr; Tel.: +33-4437-616-02
}

Received: 2 April 2020; Accepted: 13 May 2020; Published: 16 May 2020

\begin{abstract}
Spatial heterogeneity in plant and soil properties plays a key role for biogeochemical cycling, nutrient losses and ecosystem function. Different management practices are expected to induce varying levels of spatial heterogeneity in agroecosystems, but the effects of contrasting biomass removal regimes and herbivore species on grassland variability and spatial pattern have faced little attention. We carried out a spatially-explicit sampling campaign and geostatistical analyses to quantify the spatial heterogeneity of the biomass and $\mathrm{N}$ in plants and soil for three management treatments (mowing, cattle grazing and sheep grazing) within a long-term grassland experiment. All plant and soil properties showed within-site variation, irrespective of management treatment. Within-site variation in plant variables could be ranked as grazing $>$ mowing. Cattle grazing increased variability in vegetation structure, soil mineral $\mathrm{N}$ and soil $\mathrm{C}: \mathrm{N}$ compared with sheep grazing. In addition, the cattle-grazed field had a higher degree of spatial structure and a more coarse-grained pattern of spatial heterogeneity in plant properties than the sheep-grazed field. However, both grazing treatments showed spatial asynchrony in above- and below-ground responses to grazing. These results demonstrate the importance of herbivore species identity as a driver of grassland spatial heterogeneity, with implications for spatial uncoupling of nutrient cycles at the field scale.
\end{abstract}

Keywords: aboveground biomass; grazing; heterogeneity; mowing; roots; soil nitrogen; spatial autocorrelation; upland grassland

\section{Introduction}

Variability and spatial patterns in plant and soil properties are both a response to past and present abiotic and biotic processes, and are a driver of ecosystem structure and function [1-3]. Widespread evidence suggests that spatial heterogeneity plays a key role for biogeochemical cycling and nutrient losses in both managed and natural ecosystems, with significant implications for the provision of ecosystem services [4-6]. In managed agroecosystems, the prevalence of spatial heterogeneity may vary depending on the application of agricultural practices associated with cultivation, soil fertility and plant biomass harvests [7]. However, the description and quantification of spatial heterogeneity in vegetation and soil resources in relation to agricultural management is extremely limited [4], and the enhancement (or reduction) of spatial heterogeneity is rarely considered in the elaboration of ecosystem management strategies [8,9]. In order to make management recommendations, improved understanding of the impacts of different management practices on the expression of spatial heterogeneity (i.e., the occurrence and degree of plant and soil variability/spatial pattern observed) is required; simply understanding the 
consequences of spatial heterogeneity is not sufficient. Our study specifically addresses this knowledge gap, providing data of both ecological and agricultural interest.

Improved understanding of the impacts of management practices on the degree of spatial heterogeneity in above- and below-ground carbon $(\mathrm{C})$ and nitrogen $(\mathrm{N})$ pools is of particular relevance for grassland ecosystems. Grasslands are a major terrestrial biome, underpinning livestock production systems and providing key environmental and societal benefits including $C$ storage, water quality and biodiversity maintenance $[10,11]$. Within grassland fields, intrinsic heterogeneity in plant and soil properties due to pedology, topography and plant species distributions may be enhanced by the presence of grazing animals [3,12]. The presence of grazing domestic herbivores is associated with trampling, defoliation (plant tissue removal) and nutrient 'hotspots' due to deposits of urine and dung $[13,14]$. Unlike mown fields where fertilizer inputs and biomass harvests are carried out uniformly across space, non-uniform animal movements and activities (grazing, resting, attraction to water points) within grazed fields promote an uneven spatial distribution of excretal patches and a mosaic of short and tall vegetation patches [3]. Asynchrony in the spatial distribution of nutrient removal (herbivore feeding activities) and nutrient return (herbivore excretion) also generates spatial uncoupling of $\mathrm{C}$ and $\mathrm{N}$ cycles and a redistribution of nutrients within the field [8]. In the short term, grazing may alter $\mathrm{C}$ and $\mathrm{N}$ cycling by changes in i) plant growth rates and nutrient use, and ii) nutrient transformations and mineralization rates in animal excreta, with increased risks of losses by leaching and volatilization [13,15]. In the longer-term, grazing-induced changes in $\mathrm{CN}$ cycling are further enhanced by shifts in plant-soil feedbacks as well as in plant species composition and microbial community structure [16,17].

Although the general patterns and mechanisms of grassland responses to grazing are well described $[17,18]$, surprisingly few studies have explicitly quantified the impacts of grazing animals on the variability and spatial pattern of plant and soil $\mathrm{CN}$ pools. Animal social behavior and patch grazing (attraction to previously-grazed, nutrient-rich vegetation patches), coupled with positive plant-soil feedbacks, are expected to generate high variation and non-random, patchy spatial patterns of plant and soil properties in space $[14,19]$. To date, however, comparisons of grazed and ungrazed grassland sites have shown mixed results, with heterogeneity in soil properties either increasing or showing weak responses to grazing [20-22]. Responses to gradients of stocking density are more clear-cut; previous work on cattle grazing in mesic grasslands has shown that increased stocking density and grazing intensity have a strong influence on vegetation patch structure, generally increasing the proportion of short versus tall patches in space and promoting a more even forage utilization $[19,23]$. Work on sheep grazing in semi-arid grasslands also suggests that high stocking rates increase the homogeneity of plant biomass distributions within the field [24].

In contrast to the animal stocking rate, the impact of animal species on grassland variability and spatial pattern in $\mathrm{CN}$ stocks has faced little attention. In theory, differences in animal size and foraging behavior should mediate the impact of different grazing species on grassland heterogeneity and spatial pattern via differences in the size, quantity and quality of excretal returns, as well as differences in forage selectivity [22]. For example, sheep graze closer to the ground with a smaller bite size and a higher selection of legumes and dicotyledonous species in mixed grasslands compared to cattle [25]. Moreover, the smaller excretal patches of sheep are expected to have a faster nutrient turnover and generate smaller-scale patchy spatial patterns compared with the excreta of larger herbivores $[13,26]$. Indeed, the assumption that sheep grazing leads to a greater spatial uniformity than cattle grazing is a frequently-applied "rule-of-thumb" in agricultural management. However, common practices in agriculture and nature management based on practitioner experience are not systematically validated by experimental data. Whilst recent work in semi-arid grasslands has shown that plant community heterogeneity is lower in sheep-grazed pastures compared to cattle-grazed pastures at moderate grazing intensity [22], there is an absence of controlled, comparative studies of cattle- and sheep-grazing on spatial heterogeneity in temperate grassland systems. To date, comprehensive surveys of heterogeneity with spatially-explicit data on plant and soil variables are lacking, and standardized field trials are 
required to make progress in our understanding of the importance of herbivore identity as a driver of spatial heterogeneity.

The aim of this study was to simultaneously characterize plant and soil variability in a semi-natural grassland subjected to contrasting management practices, with a particular focus on the comparison between cattle- and sheep-grazing effects on within-field spatial heterogeneity. Spatial patterns in plant and soil $\mathrm{C}$ and $\mathrm{N}$ content were examined as part of a long-term management trial in an upland temperate grassland in the French Massif Central Region by combining a spatial sampling design with geostatistical analysis. We predicted that grazing would promote greater within-field variation compared with mowing, and hypothesized that for a given animal stocking rate: (i) cattle grazing induces a greater variability in plant and soil properties than sheep grazing, and (ii) the patchy spatial pattern of plant and soil properties is expressed at a larger spatial scale in cattle-grazed paddocks than that in sheep-grazed paddocks. We also examined whether the magnitude and direction of animal grazing effects on heterogeneity show similar patterns above- and below-ground.

\section{Materials and Methods}

\subsection{Study Site}

The study was conducted in a flat upland grassland area located in the French Massif Central $\left(45^{\circ} 43^{\prime} 43^{\prime \prime} \mathrm{N}, 03^{\circ} 1^{\prime} 21^{\prime \prime} \mathrm{E}, 880 \mathrm{~m}\right.$ a.s.l.). The climate is semi-continental, with a mean annual temperature of $8.7^{\circ} \mathrm{C}$ and a mean annual precipitation of $800 \mathrm{~mm}$. The vegetative community is dominated by grasses (Lolium perenne, Elytrigia repens, Festuca arundinacea, Holcus lanatus). Other species include smaller graminoids (Agrostis capillaris, Festuca rubra, Poa pratensis, Poa trivialis, Trisetum flavescens), forbs (Taraxacum officinalis, Veronica chamaedris) and legumes (Trifolium repens, Trifolium pratense). The soil is classified as a Cambic soil ( $43 \%$ sand, $36 \%$ silt, $21 \%$ clay, $5.2 \%$ organic matter) with a pH of 6.2 . Historically, this area has been subject to a mid-intensive grassland management scheme (early season mowing with medium inputs of organic fertilizer, late seasonal grazing). From 2003, the area was subject to mowing (three times a year) with no fertilizer input.

In January 2005, three management treatments were established on fenced sites randomly established within the study area as part of the SOERE ACBB agroecosystems management trial (Theix permanent grassland site, http://www.soere-acbb.com): mowing with fertilizer addition (three cuts per year at end May, mid-July and early October, manual application of NPK fertilizer as slow release granules in three splits with a total $240 \mathrm{Kg} \mathrm{N} \mathrm{ha}^{-1} \mathrm{yr}^{-1}$ ), and low-intensity cattle or sheep grazing in a rotational grazing system with no fertilizer addition. In both grazing treatments, the stocking rate was 0.65 livestock units (LU) per hectare and per year where $1 \mathrm{LU}$ is $600 \mathrm{~kg}$ liveweight. This stocking rate corresponds to $50 \%$ of the LU required for complete use of the available on-site herbage. Grazing was applied in five rotations each year: mid-April, end May, early July, early September and November, with grazing periods ranging from 4-12 days depending on the vegetation state. Plot sizes were $400 \mathrm{~m}^{2}, 1100 \mathrm{~m}^{2}$ and $2200 \mathrm{~m}^{2}$ for the mown, sheep-grazed and cattle-grazed treatments, respectively. Collectively, these three management treatments represent land use practices commonly found in grasslands in the region.

\subsection{Field Sampling}

In mid-September 2009, four years after the start of the experimental treatments, we marked out one $10 \mathrm{~m} \times 20 \mathrm{~m}$ study plot at the center of three fenced sites representing each of the different management practices (fenced sites were 30-50 m apart). Field sampling in each plot was carried out at the end of the plant growing season (end of September 2009) to examine the maximum effect of grazing; previous work has shown that effects of grazing on both vegetation structure and soil mineral $\mathrm{N}$ become progressively more marked over the course of the plant growing season $[27,28]$. Field sampling corresponded to three weeks after the end of the September grazing period for grazed paddocks, and 2.5 months after the previous cutting event for the mown field. 
Spatial heterogeneity in soil properties and vegetation was assessed using a grid of 120 sampling points in a partly nested design across each study plot (Figure 1). In brief, a regular grid was spaced at $2.5 \mathrm{~m}$ intervals (45 sampling points) and then divided into three subplots, each consisting of eight $2.5 \mathrm{~m} \times 2.5 \mathrm{~m}$ cells. Within each subplot, one $2.5 \mathrm{~m} \times 2.5 \mathrm{~m}$ cell was randomly selected, and nested sample points were defined on an increasingly fine scale $(1.25 \mathrm{~m}, 0.63 \mathrm{~m}, 0.31 \mathrm{~m}, 0.16 \mathrm{~m}$ and $0.08 \mathrm{~m})$ resulting in a further 25 sampling points per subplot. Geographic coordinates of each sample point were established (Trimble R8 GPS Systems, Trimble Navigation Limited, Sunnyvale, CA, USA). This sampling scheme was chosen to optimize variogram modeling following [29]. We recognize that the design is limited because the fenced sites define only one formal replicate per treatment, but (i) this is common practice in geostatistical studies given the high within-site sampling effort necessary for determining variability of soil properties in ecosystems [2,20,30], and (ii) we consider the management treatments to be sufficiently distinct and well-established to drive site differences and to allow for detection of land use effects.

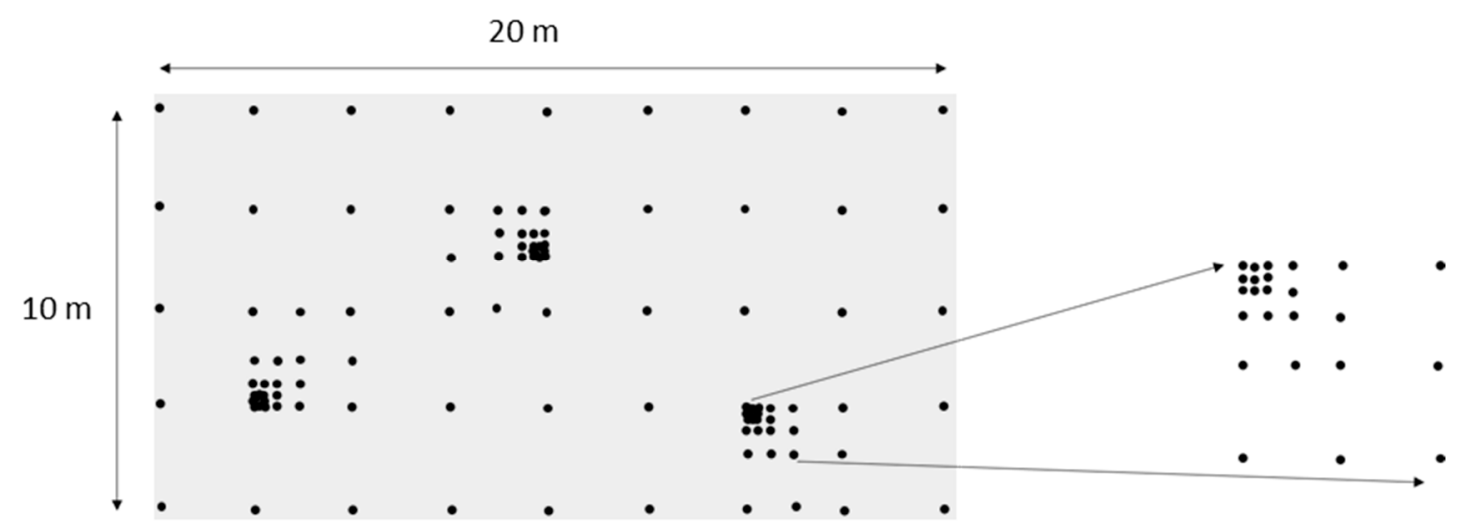

Figure 1. Illustration of the spatial sampling scheme deployed within each management treatment (the exact position of nested subplots varies between fields).

Maximum vegetation height and aboveground plant biomass (cut at ground level) was recorded in a $3 \mathrm{~cm} \times 3 \mathrm{~cm}$ zone at each of the 120 sampling points per plot. Average plant species number in the biomass of sampling points ranged from 2.5 to 2.8 and did not differ across treatments (data not shown). A soil core (2.5 cm diameter, $10 \mathrm{~cm}$ depth) was collected from the center of each harvested zone, and all soil cores were maintained at $<5^{\circ} \mathrm{C}$ prior to analysis.

\subsection{Soil and Vegetation Analyses}

Aboveground biomass samples were sorted into green and senescent material. Soil cores were sieved $(2 \mathrm{~mm})$ to produce a well-mixed, fine soil sample per core; the remaining below-ground plant biomass, coarse soil and organic debris were washed to extract and separate roots and rhizomes. All plant biomass samples (green shoots, senescent shoots, roots, rhizomes) were then dried at $60{ }^{\circ} \mathrm{C}$ for $48 \mathrm{~h}$ and weighed. Total $\mathrm{C}$ and $\mathrm{N}$ content in aboveground green biomass and root samples was determined with an elemental combustion analyzer (Flash EA 1112 CNS analyzer, ThermoFinnigan, Milan, Italy); we considered that the $\mathrm{N}$ content of these two plant fractions was most likely to be influenced by local soil $\mathrm{N}$ conditions.

Available ammonium and nitrate were extracted from freshly-sieved soil by shaking $5 \mathrm{~g}$ of soil with $20 \mathrm{~mL} 1 \mathrm{M} \mathrm{KCl}$ for $1 \mathrm{~h}$. The KCL extracts were filtered through Whatman glass microfiber filters and analyzed by colorimetric measurements (Bran \& Luebbe AutoAnalyser 3, Hamburg, Germany). Additional sieved soil sub-samples were oven-dried $\left(105^{\circ} \mathrm{C}, 24 \mathrm{~h}\right)$ to determine soil water content per soil core. The remaining sieved soil was dried at $60^{\circ} \mathrm{C}$ for $48 \mathrm{~h}$ and ground for determination of total carbon and nitrogen using an elemental combustion analyzer (Flash EA 1112 CNS analyzer, ThermoFinnigan, Milan, Italy). 


\subsection{Statistical Analysis}

Standard deviation and coefficients of variation $(\mathrm{CV}$, standard deviation/mean $\times 100)$ were used to assess the absolute and relative variation, respectively, of plant and soil properties within each treatment. Treatment differences in $\mathrm{CV}$ were tested using a nonparametric bootstrap test of the equality of the CV following [31].

Patterns of spatial autocorrelation in plant and soil properties were examined in the cattle- and sheep-grazed treatments using semivariance analysis [30]. Semivariance describes the degree of spatial dependence between measurement points as a function of distance. Envelopes for semivariance were computed by permutation of the data values at the spatial locations (1000 permutations), and semivariograms were fitted for each variable where significant spatial autocorrelation was detected. A spherical semi-variogram model was fitted to facilitate comparisons; unlike other commonly-used models, the spherical model has a true range parameter (i.e., a distance at which the variogram is constant). The magnitude of spatial dependence in each variate was estimated as the proportion of total sample variation explained by structural variance $\left(C /\left[C+C_{0}\right]\right)[29]$. This index ranges from 0 to 1 , where values approaching 1 indicate high spatial dependence over the distance examined. The distance over which any spatial dependence is expressed was given by the model range. When the range is small, or where there is no detectable spatial dependence for the variation, the variate is considered to be randomly-distributed at the scale investigated [30]. Non-random spatial distributions were classified following definitions given by [32].

Statistical and geostatistical analyses were performed in R (R Development Core Team, 2008; geoR library).

\section{Results}

\subsection{Impacts of Management on Within-Field Variation}

Plant and soil properties showed significant treatment differences at the end of the plant growing season; on average, grazing treatments had a higher aboveground standing biomass and senescent tissue (lower \% green material) but lower plant and soil N concentrations compared to the mown, fertilized treatment (Figure S1, Table S1). In addition, mean vegetation height, plant biomass (both above- and belowground), \% green tissue and shoot $\mathrm{C}: \mathrm{N}$ were lower in the cattle-grazed pasture compared to the sheep-grazed pasture at the end of the growing season (Table S1). However, there was a high degree of within-site variation in all of the soil and vegetation parameters measured (Figure S1, Table 1).

Standard deviations for vegetation height, aboveground biomass, \% green tissue and C:N of root and shoot biomass were higher in grazed treatments compared to the mown pasture (Figure S1). Similar rankings of response to management treatments were obtained for the coefficients of variation of these variates (Table 1). In contrast, standard deviations and coefficients of variation of soil mineral $\mathrm{N}$ pools could be ranked: cattle grazing $>$ mowing $>$ sheep grazing (Table 1, Figure S1).

Eight out of the 12 recorded plant and soil properties had higher standard deviations under cattle grazing compared to sheep grazing (Figure S1). Coefficients of variation were significantly higher under cattle grazing compared to sheep grazing for vegetation height, aboveground biomass and \% green tissue (Table 1). Soil mineral $\mathrm{N}$ pools and soil C:N also had higher $\mathrm{CV}$ in the cattle-grazed pasture compared to the sheep-grazed pasture. Relative variation in plant N concentration and belowground plant biomass did not, however, differ between the two grazing treatments (Table 1). 
Table 1. Variability (CV, coefficient of variation) of vegetation and soil $(0-10 \mathrm{~cm})$ parameters in relation to management treatments.

\begin{tabular}{|c|c|c|c|}
\hline \multirow{2}{*}{ Variable } & \multicolumn{3}{|c|}{ Management Treatment $\S$} \\
\hline & Mowing + NPK & Sheep-Grazing & Cattle-Grazing \\
\hline Vegetation height $(\mathrm{cm})$ & $35.4^{\mathrm{a}}$ & $38.3^{\mathrm{a}}$ & $54.6^{\mathrm{b}}$ \\
\hline Aboveground standing dry mass $\left(\mathrm{kg} \mathrm{m}^{-2}\right)$ & $64.6^{\mathrm{a}}$ & $48.1^{b}$ & $65.7^{\mathrm{a}}$ \\
\hline Green shoot material (\%) & $13.9^{\mathrm{a}}$ & $35.5^{b}$ & $72.4^{\mathrm{c}}$ \\
\hline Shoot $[\mathrm{N}] *\left(\mathrm{mg} \mathrm{N} \mathrm{g}^{-1}\right.$ shoot dry mass $)$ & $16.5^{\mathrm{a}}$ & $23.8^{\mathrm{b}}$ & $28.5^{b}$ \\
\hline Shoot $\mathrm{C} / \mathrm{N}^{*}$ & $19.9^{\mathrm{a}}$ & $21.6^{\mathrm{ab}}$ & $27.3^{b}$ \\
\hline Rhizome dry mass $\left(\mathrm{kg} \mathrm{m}^{-2}\right)$ & $84.6^{\mathrm{a}}$ & $83.5^{\mathrm{a}}$ & $68.9^{\mathrm{a}}$ \\
\hline Root dry mass $\left(\mathrm{kg} \mathrm{m}^{-2}\right)$ & $80.4^{\mathrm{a}}$ & $55.8^{\mathrm{b}}$ & $47.6^{\mathrm{b}}$ \\
\hline Root [N] (mg $\mathrm{N} \mathrm{g}^{-1}$ root dry mass) & $14.2^{\mathrm{a}}$ & $15.1^{\mathrm{a}}$ & $13.6^{\mathrm{a}}$ \\
\hline Root C/N & $14.1^{\mathrm{a}}$ & $14.6^{\mathrm{a}}$ & $14.1^{\mathrm{a}}$ \\
\hline Soil $\mathrm{NO}_{3}-\mathrm{N}\left(\mu \mathrm{g} \mathrm{N} \mathrm{g}{ }^{-1}\right.$ dry soil) & $128^{\mathrm{a}}$ & $31.1^{\mathrm{b}}$ & $192^{c}$ \\
\hline Soil $\mathrm{NH}_{4}-\mathrm{N}(\mu \mathrm{g} \mathrm{N} \mathrm{g}-1$ dry soil) & $121^{\mathrm{a}}$ & $42.4^{\mathrm{b}}$ & $224^{c}$ \\
\hline Soil C/N & $5.44^{\mathrm{a}}$ & $3.30^{b}$ & 4.29 ac \\
\hline
\end{tabular}

* Analysis based on green shoot material only. \$ Significant differences between treatment CVs are indicated by superscript different letters based on pair-wise non-parametric bootstrapping tests and Bonferroni adjustments.

\subsection{Spatial Patterns in Relation to Grazing Animal Identity}

The cattle-grazed treatment showed a higher degree of spatial structure in plant and soil properties compared with the sheep-grazed treatment. Under cattle grazing, five out of 12 variables had spatial patterns that differed from random, whereas under sheep grazing, only two plant variables showed significant spatial autocorrelation (Figures 2 and 3, Table 2). Irrespective of grazing treatment, aboveground plant variables expressed more spatial patterning than belowground variables; belowground biomass and soil nitrogen content did not show any spatial autocorrelation in either grazing treatment.

Table 2. Summary of semivariogram model parameters for vegetation and soil $(0-10 \mathrm{~cm})$ properties deviating from random spatial distributions under cattle and sheep grazing.

\begin{tabular}{rllll}
\hline \multirow{2}{*}{ Treatment } & \multicolumn{1}{c}{ Variable } & Spatial Pattern * & Range $(\mathbf{m})$ & $\begin{array}{c}\text { Spatial Dependence } \\
\left(\mathrm{C} /\left[\mathrm{C}+\mathrm{C}_{\mathbf{0}}\right] \mathbf{)}\right.\end{array}$ \\
\hline \multirow{2}{*}{ Sheep Grazing } & Shoot [N] & Patchy & 0.68 & 1 \\
& Shoot C:N & Patchy & 0.66 & 0.75 \\
& Vegetation height & Periodic & 1.83 & 1 \\
& Aboveground & Periodic & 1.18 & 0.92 \\
Cattle Grazing & standing biomass & Patchy & 2.44 & 0.44 \\
& Shoot C:N & Patchy & 1.32 & 0.46 \\
& Root [N] & Patchy & 1.03 & 0.51 \\
\hline
\end{tabular}

${ }^{*}$ Classifications following [32]. 

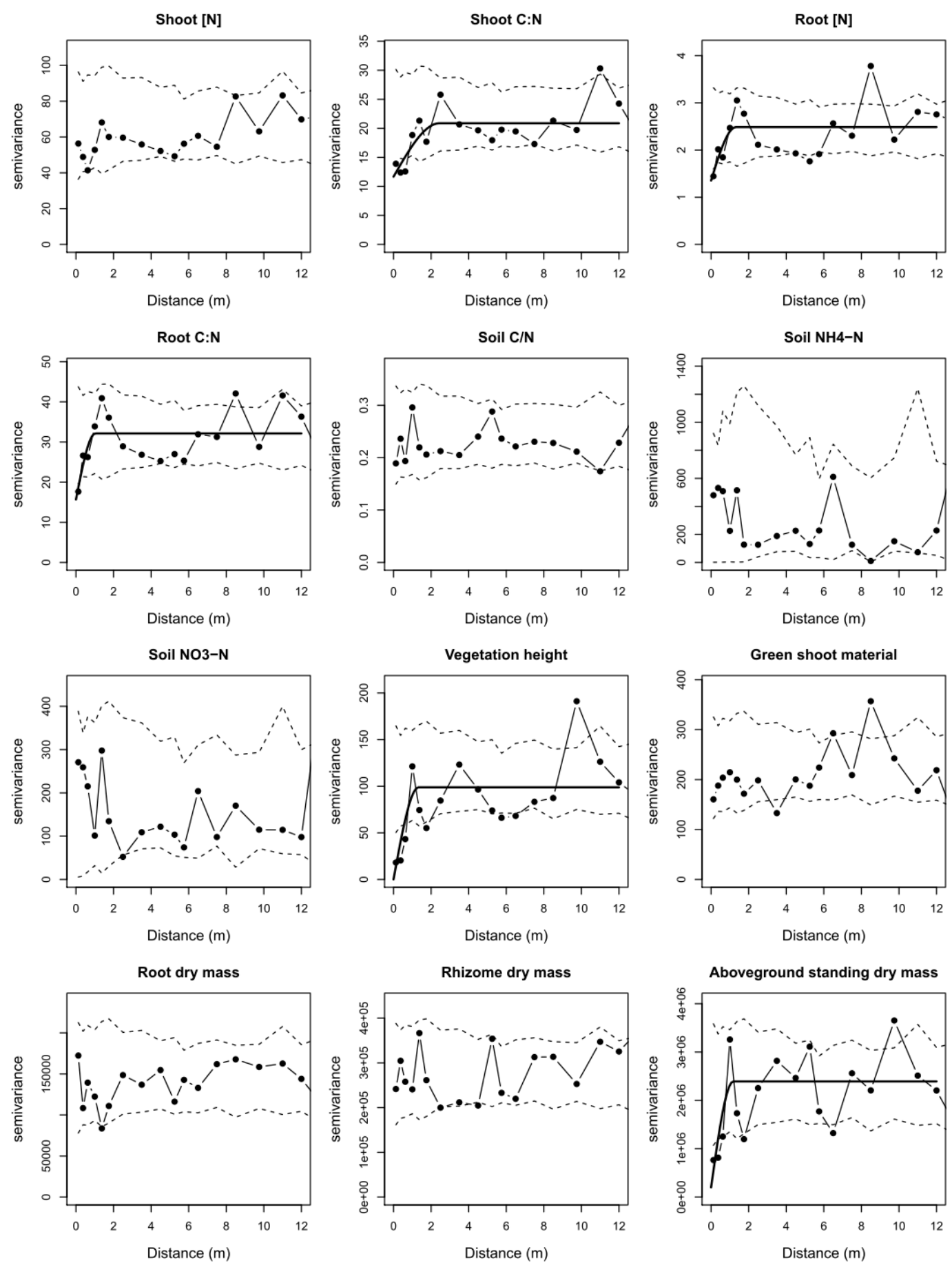

Figure 2. Semivariance of plant and soil properties $(0-10 \mathrm{~cm}$ soil layer) under cattle grazing. Dashed lines show the $95 \%$ interval of 1000 random permutations. Solid lines represent fitted spherical models where significant spatial autocorrelation was detected. Measurement units of variables are given in Table 1. 

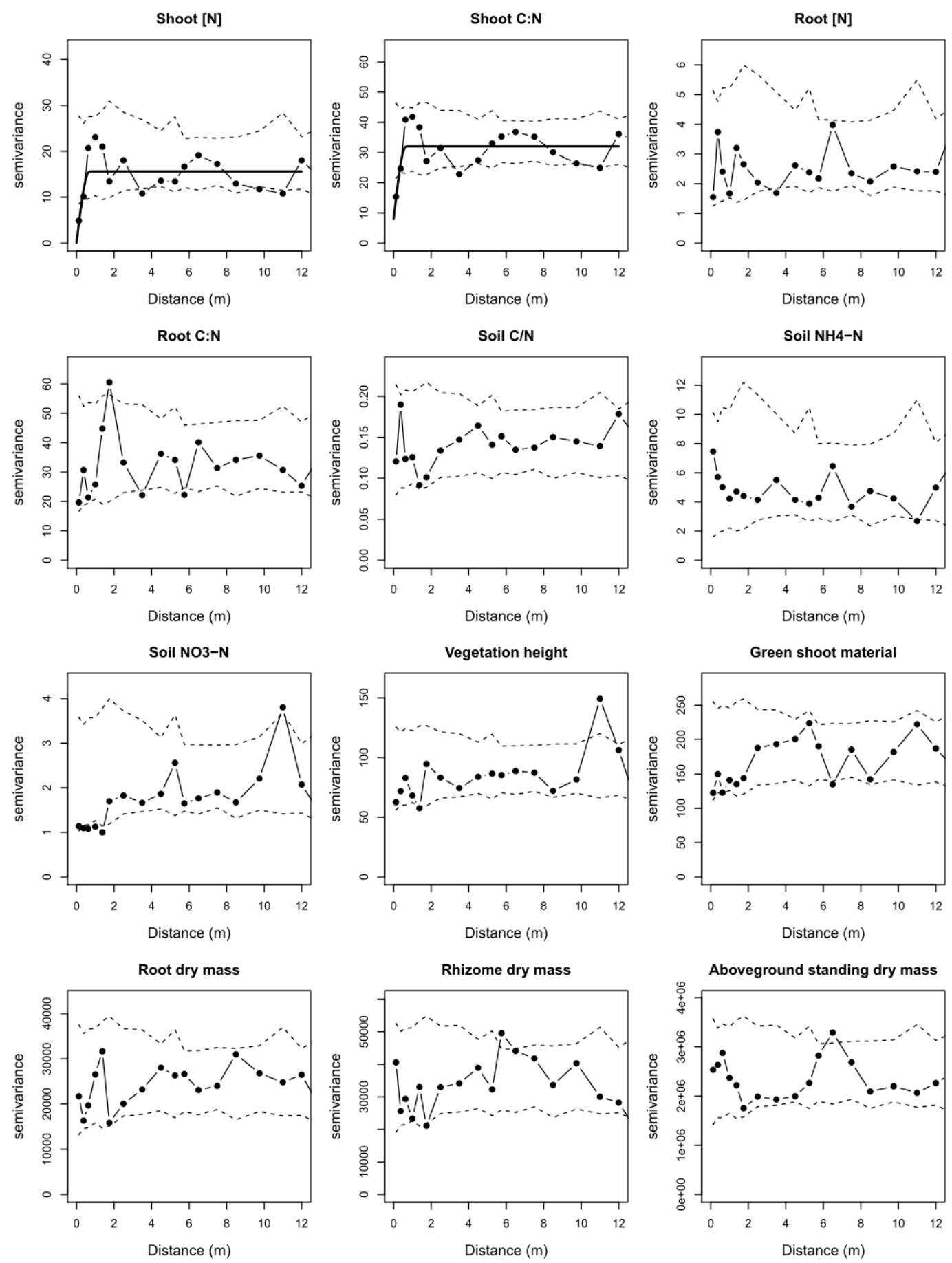

Figure 3. Semivariance of plant and soil properties (0-10 cm soil layer) under sheep grazing. Dashed lines show $95 \%$ interval of 1000 random permutations. Solid lines represent fitted spherical models where significant spatial autocorrelation was detected. Measurement units of variables are given in Table 1.

In the cattle-grazing treatment, aboveground biomass and vegetation height had high spatial dependence ( $\mathrm{C} /\left[\mathrm{C}+\mathrm{C}_{0}\right]$ close to 1 ) and a periodic spatial pattern (Figure 2, Table 2). Plant biochemical properties (root $\mathrm{N}$ concentration, root and shoot $\mathrm{C}: \mathrm{N}$ ) had low spatial dependence and displayed a patchy spatial pattern. All variables with significant spatial autocorrelation in the cattle-grazing treatment had ranges between 1 and $2.5 \mathrm{~m}$ (Table 2). 
In the sheep-grazing treatment, shoot $\mathrm{N}$ concentration and shoot $\mathrm{C}: \mathrm{N}$ had high spatial dependence $\left(C /\left[C+C_{0}\right]\right.$ close to 1$)$ and a patchy spatial pattern (Figure 3, Table 2). The range (distance) over which there was spatial autocorrelation was very similar $(<1 \mathrm{~m})$ for both shoot $\mathrm{N}$ concentration and shoot $\mathrm{C}: \mathrm{N}$ (Table 2). Moreover, the magnitude of spatial dependence for shoot $\mathrm{C}: \mathrm{N}$ was higher in the sheep-grazed pasture compared to the cattle grazed pasture (Table 2).

\section{Discussion}

Spatial heterogeneity is a pervasive feature in all ecosystems, driving pattern-process relationships at multiple spatial scales [33]. Quantifying spatial heterogeneity in managed ecosystems is, therefore, a necessary step for determining when heterogeneity is functionally important, and for improving the accuracy of biogeochemical cycling models [3]. In the present study, we examined within-field variation and spatial pattern from the fine- to medium-scale (distances between measurement points ranging from $12 \mathrm{~cm}$ to $12 \mathrm{~m}$ ), considering both plant and soil properties. As expected, we found that the mechanization technique of mowing was associated with lower variability in above- and below-ground plant parameters compared to that of grazed fields. Variability of soil mineral nitrogen in the mown field was somewhat higher than expected, possibly linked to the manual fertilizer application or interactions between inorganic $\mathrm{N}$ and different species present within the field [34], but was still considerably lower than that of the cattle-grazed field. Lower spatial variability in mown fields may generate benefits in terms of nutrient cycling, at the expense of heterogeneity-induced increases in biodiversity [3,20,35]. Indeed, studies of $\mathrm{N}$ losses in managed grasslands have shown significantly lower $\mathrm{N}_{2} \mathrm{O}$ emissions and nitrate leaching in mown fields compared to cattle-grazed fields [36,37].

Our first hypothesis was that cattle grazing would promote greater variability in plant and soil properties compared with sheep grazing at the same stocking rate. This hypothesis was broadly supported by our data; values of standard deviations could be ranked as cattle grazing $>$ sheep grazing for the majority of the variates in this study, and six out of 12 variates showed significantly higher CV under cattle grazing. The magnitude of increase in variation in the cattle-compared to the sheep-grazed field depended on the variate examined (range of increase from +30 to $+500 \%$ ), with greatest treatment differences recorded for soil mineral $\mathrm{N}$. This strong contrast in the variability of soil mineral $\mathrm{N}$ between the two grazing treatments, driven by the presence of some very high values in the cattle-grazed field, is consistent with differences in the size and quantity of excretal patches produced by the different herbivore species [13]. Smaller excretal patches have a faster nutrient turnover and more efficient recycling, with reduced risks of $\mathrm{N}$ losses by leaching or gaseous emissions [26,38]). At the same time, high variation (including high absolute values) of soil mineral $\mathrm{N}$ can promote growth of exploitative plant species and enhance plant biomass production $[38,39]$. The discrepancy in the magnitude of treatment differences between the variability of soil mineral $\mathrm{N}$ and plant biomass observed in the present study may stem from lag effects (plants at the end of the growing season are less able to utilize available $\mathrm{N}$ ) and nutrient colimitation, as well as interactions between plant growth and animal grazing behavior [3].

Reduced within-field variation has both direct and indirect effects on $\mathrm{CN}$ cycling, plant community structure and invertebrate diversity $[3,19]$. In our study, we used absolute and relative measures of variation as complementary metrics of spatial heterogeneity. Standard deviations are descriptive statistics that are biologically intuitive, but are sensitive to sampling methodology. In contrast, coefficients of variation are standardized and useful for the comparison of variables with different units or markedly different values, although they may mask differences between cases with high variance/high mean versus low variance/low mean. This shortcoming in the use of CV arose in our study for root and rhizome biomass data; CV values showed no significant differences between cattleand sheep-grazing treatments despite clear differences in the empirical distributions of these variables (Figure S1). Standard deviations of root and rhizome biomass in the cattle-grazed field were double those observed in the sheep-grazed pasture, reinforcing the idea of a higher variability in functional 
states in cattle-grazed pastures at a given level of grazing intensity. Such observations confirm the value of presenting multiple metrics for spatial analysis [40].

Under extensive grazing, repeated defoliation of previously-grazed, short vegetation of high nutritive value or 'patch grazing' is a relatively common phenomenon in grasslands $[12,14,19]$. Animal excreta (urine, dung) are also associated with patches of nutrient inputs [13]. Based on both differences in foraging selectivity between cattle and sheep, and in the size of their excretal patches, our second hypothesis predicted that patchy spatial patterns in plant and soil properties would be detected at a larger spatial scale in cattle-grazed paddocks than in sheep-grazed paddocks. Our results generally supported this hypothesis since the range (distance) over which we detected significant spatial patterns was consistently greater in the cattle-grazed treatment compared to the sheep-grazed pasture. However, relatively few plant variables showed spatial autocorrelation at the fine- to medium-scale, and soil mineral $\mathrm{N}$ showed no spatial patterns in either treatment despite the high levels of within-treatment variation observed.

The absence of fine-scale spatial patterns in soil mineral $\mathrm{N}$ in our study agrees with previous findings from fields extensively-grazed by sheep [24], and may in part reflect the dynamic nature (uptake, transformations) of mineral $\mathrm{N}$ forms in soil, as well as variation in the spatial distribution of excretal patches over time [13,41,42]. Nevertheless, fine-scale spatial patterns in soil $\mathrm{N}$ have been demonstrated at high animal stocking rates [22], and coarser-grained spatial patterns in soil $\mathrm{N}$ are likely to occur within both cattle- and sheep-grazed fields with zones of higher concentration near watering and resting points [27]. The lack of spatial pattern in aboveground biomass in our sheep-grazed pasture is more surprising, and contrasts with the fine-scale patterns reported for plant biomass under extensive sheep-grazing elsewhere [24]. Both sheep social behavior and plant species spatial patterns have been shown to modify sheep foraging in heterogeneous pastures $[43,44]$, and it is possible that the impacts of sheep grazing on spatial patterns in plant biomass in our study were masked by other processes. Of course, we cannot rule out the possibility that an increased number of measurement points at small distances $(<2 \mathrm{~m})$ would also have improved our power to detect fine-scale spatial patterns.

Interestingly, plant aboveground biomass and vegetation height showed periodic spatial patterns rather than patchy distributions in the cattle-grazed pasture. Spatially-periodic patterns, a special case of regular distributions, often reflect biomass-water feedbacks or biotic patterning processes such as plant competition for resources, allelopathy and facilitation [45]. As far as we are aware, this is the first report of spatially-periodic patterns in vegetation height or biomass in grazed temperate grasslands that is unrelated to topography. Alternating bands or 'spots' of vegetation states (e.g., low versus high) across space may in part be linked to plant-animal feedbacks in cattle-grazed pastures [46]. Cattle dung patches are known to have an initially adverse effect on vegetation in the immediately-affected area (via suffocation), but herbivore avoidance of herbage growing around dung patches may promote increasing vegetation height with increasing distance from the excretal patch. Herbivore avoidance behavior of dung is stronger in cattle compared to sheep [47], and can also lead to transient changes in fine-scale plant community dynamics [46]. It is notable that, unlike aboveground plant biomass, belowground plant biomass did not show any spatial patterns in response to cattle grazing. Spatial asynchrony in above- and below-ground responses to grazing could have significant implications for both plant-plant interactions and plant-soil feedbacks involved in the regulation and coupling of grassland CN cycling $[8,48]$.

\section{Conclusions}

To our knowledge, this is the first study to explicitly examine the importance of grazing animal identity on spatial heterogeneity in vegetation structure, plant $\mathrm{N}$ pools and soil $\mathrm{N}$ content in managed temperate grasslands. By controlling for stocking rate and pedoclimatic conditions, our results demonstrate that plant and soil properties are generally more variable in the presence of cattle than sheep under extensive rotational grazing. At the end of the plant growing season, spatial patterns in plant variables were also more prevalent in the cattle-grazed pasture compared to the 
sheep-grazed pasture. In general, patterns of spatial heterogeneity in plant variables differed aboveand belowground, with implications for longer-term $\mathrm{CN}$ cycling and plant community dynamics within the field. These findings underline the importance of cattle as a driver of the magnitude and spatial scale of heterogeneity in managed grasslands, suggesting that attempts to represent spatial heterogeneity in field-scale biogeochemical models should be pursued for cattle-grazed grasslands (e.g., [15]). Further studies are required to verify our findings for a greater range of cattle- and sheep-grazed fields at multiple sampling dates, and to explore the role of temporal variability as a driver of asynchrony between above-and belowground spatial patterns.

Supplementary Materials: The following are available online at http://www.mdpi.com/2073-4395/10/5/716/s1, Figure S1: Empirical density distributions of plant and soil properties (0-10 cm soil layer) in each management treatment. Standard deviations for each variate are presented $(n=120)$, Table S1: Mean vegetation and soil $(0-10$ $\mathrm{cm}$ profile) properties at the end of the plant growing season in experimental treatments.

Author Contributions: Conceptualization, J.M.G.B.; methodology, J.M.G.B., A.T.; formal analysis, J.M.G.B., J.P.; writing-original draft preparation, J.M.G.B., J.P.; writing—review and editing, A.T. All authors have read and agreed to the published version of the manuscript.

Funding: This research received no external funding.

Acknowledgments: We thank P. Pichon, F. Giacomoni, A. Salcedo, A. Jouve, A. Cantarel and R. Pilon for assistance with data collection. Thanks also to L. Andanson for colorimetry measurements, JL. Ollier for CNS measurements and F. Louault for site information.

Conflicts of Interest: The authors declare no conflict of interest.

\section{References}

1. Tilman, D. Dynamics and Structure of Plant Communities; Princeton University Press: Princeton, NL, USA, 1988.

2. Burke, I.C.; Lauenroth, W.K.; Riggle, R.; Brannen, P.; Madigan, B.; Beard, S. Spatial variability of soil properties in the shortgrass steppe: The relative importance of topography, grazing, microsite and plant species in controlling spatial patterns. Ecosystems 1999, 2, 422-438. [CrossRef]

3. Bloor, J.M.G.; Pottier, J. Grazing and spatial heterogeneity: Implications for grassland structure and function. In Grassland Biodiversity and Conservation in a Changing World; Mariotte, P., Kardol, P., Eds.; Nova Science Publishers, Inc.: Hauppage, NY, USA, 2014; pp. 135-162.

4. García-Palacios, P.; Maestre, F.T.; Bardgett, R.D.; De Kroon, H. Plant responses to soil heterogeneity and global environmental change. J. Ecol. 2012, 100, 1303-1314. [CrossRef]

5. McGranahan, D.A.; Hovick, T.J.; Elmore, R.D.; Engle, D.M.; Fuhlendorf, S.D. Moderate patchiness optimizes heterogeneity, stability, and beta diversity in mesic grassland. Ecol. Evol. 2018, 8, 5008-5015. [CrossRef]

6. Turner, M.G.; Donato, D.C.; Romme, W.H. Consequences of spatial heterogeneity for ecosystem services in changing forest landscapes: Priorities for future research. Landsc. Ecol. 2013, 28, 1081-1097. [CrossRef]

7. Robertson, G.P. The impact of soil and crop management practices on soil spatial heterogeneity. In Soil Biota Management in Sustainable Farming Systems; Pankhurse, C.E., Doube, B.M., Gupta, V.V., Grace, P.R., Eds.; CSIRO: East Melbourne, Australia, 1994; pp. 156-161.

8. Vertes, F.; Delaby, L.; Klumpp, K.; Bloor, J.M.G. C-N-P uncoupling in grazed grasslands and environmental implications of management intensification. In Agroecosystem Diversity; Lemaire, G., Carvalho, P.C.D.F., Kronberg, S., Recous, S., Eds.; Academic Press-Elsevier: Amsterdam, The Netherlands, 2019; pp. 15-34.

9. Dronova, I. Environmental heterogeneity as a bridge between ecosystem service and visual quality objectives in management, planning and design. Landsc. Urban Plan. 2017, 163, 90-106. [CrossRef]

10. O'Mara, F.P. The role of grasslands in food security and climate change. Ann. Bot. 2012, 110, 1263-1270. [CrossRef] [PubMed]

11. Bengtsson, J.; Bullock, J.M.; Egoh, B.; Everson, T.; O'Connor, T.; O’Farrell, P.J.; Smith, H.G.; Lindborg, R. Grasslands-more important for ecosystem services than you might think. Ecosphere 2019, 10, e02582. [CrossRef]

12. Adler, P.B.; Raff, D.; Lauenroth, W.K. The effect of grazing on the spatial heterogeneity of vegetation. Oecologia 2001, 128, 465-479. [CrossRef] 
13. Haynes, R.J.; Williams, P.H. Nutrient cycling and soil fertility in the grazed pasture ecosystem. Adv. Agron 1993, 49, 119-200. [CrossRef]

14. Parsons, A.J.; Dumont, B. Spatial heterogeneity and grazing processes. Anim. Res. 2003, 52, 161-179. [CrossRef]

15. Hutchings, N.J.; Olesen, J.E.; Petersen, B.M.; Berntsen, J. Modelling spatial heterogeneity in grazed grassland and its effects on nitrogen cycling and greenhouse gas emissions. Agric. Ecosyst. Environ. 2007, 121, 153-163. [CrossRef]

16. Milchunas, D.G.; Sala, O.E.; Lauenroth, W.K. A generalized model of the effects of grazing by large herbivores on grassland community structure. Am. Nat. 1988, 132, 87-106. [CrossRef]

17. Bardgett, R.D.; Wardle, D.A. Herbivore-mediated linkages between aboveground and belowground communities. Ecology 2003, 84, 2258-2268. [CrossRef]

18. Díaz, S.; Lavorel, S.; McIntyre, S.; Falczuk, V.; Casanoves, F.; Milchunas, D.G.; Skarpe, C.; Rusch, G.M.; Sternberg, M.; Noy-Meir, I.; et al. Plant trait responses to grazing-a global synthesis. Glob. Chang. Biol. 2007, 12, 1-29. [CrossRef]

19. Tonn, B.; Raab, C.; Isselstein, J. Sward patterns created by patch grazing are stable over more than a decade. Grass Forage Sci. 2019, 74, 104-114. [CrossRef]

20. Zhou, Z.; Sun, O.J.; Luo, Z.; Jin, H.; Chen, Q.; Han, X. Variation in small-scale spatial heterogeneity of soil properties and vegetation with different land use in semiarid grassland ecosystem. Plant Soil 2008, 310, 103-112. [CrossRef]

21. Hirobe, M.; Kondo, J.; Enkhbaatar, A.; Amartuvshin, N.; Fujita, N.; Sakamoto, K.; Yoshikawa, K.; Kielland, K. Effects of livestock grazing on the spatial heterogeneity of net soil nitrogen mineralization in three types of Mongolian grasslands. J. Soils Sediments 2013, 13, 1123-1132. [CrossRef]

22. Liu, J.; Feng, C.; Wang, D.L.; Wang, L.; Wilsey, B.J.; Zhong, Z.W. Impacts of grazing by different large herbivores in grassland depend on plant species diversity. J. Appl. Ecol. 2015, 52, 1053-1062. [CrossRef]

23. Barnes, M.K.; Norton, B.E.; Maeno, M.; Malechek, J.C. Paddock size and stocking density affect spatial heterogeneity of grazing. Rangel. Ecol. Manag. 2008, 61, 380-388. [CrossRef]

24. Lin, Y.; Hong, M.; Han, G.; Zhao, M.; Bai, Y.; Chang, S.X. Grazing intensity affected spatial patterns of vegetation and soil fertility in a desert steppe. Agric. Ecosyst. Environ. 2010, 138, 282-292. [CrossRef]

25. Rook, A.J.; Dumont, B.; Isselstein, J.; Osoro, K.; Wallis DeVries, M.F.; Parente, G.; Mills, J. Matching type of livestock to desired biodiversity outcomes in pastures-A review. Biol. Conserv. 2004, 119, 137-150. [CrossRef]

26. Bakker, E.S.; Ritchie, M.E.; Olff, H.; Milchunas, D.G.; Knops, J.M.H. Herbivore impact on grassland plant diversity depends on habitat productivity and herbivore size. Ecol. Lett. 2006, 9, 780-788. [CrossRef] [PubMed]

27. Bogaert, N.; Salomez, J.; Vermoesen, A.; Hofman, G.; Van Cleemput, O.; Van Meirvenne, M. Within-field variability of mineral nitrogen in grassland. Biol. Fertil. Soils 2000, 32, 186-193. [CrossRef]

28. Rossignol, N.; Chadoeuf, J.; Carrère, P.; Dumont, B. A hierarchical model for analysing the stability of vegetation patterns created by grazing in temperate pastures. Appl. Veg. Sci. 2011, 14, 189-199. [CrossRef]

29. Isaaks, E.H.; Srivastava, R.M. An Introduction to Applied Geostatistics; Oxford University Press: New York, NY, USA, 1989.

30. Gross, K.L.; Pregitzer, K.S.; Burton, A.J. Spatial variation in nitrogen availability in three successional plant communities. J. Ecol. 1995, 83, 357-367. [CrossRef]

31. Amiri, S.; Zwanzig, S. An improvement of the nonparametric bootstrap test for the comparison of the coefficient of variations. Commun. Stat. Simulat. 2010, 39, 1726-1734. [CrossRef]

32. Fortin, M.J.; Dale, M.R.T. Spatial Analysis: A Guide for Ecologists; Cambridge University Press: Cambridge, UK, 2005.

33. Wiens, J.A. Spatial scaling in ecology. Func. Ecol. 1989, 3, 385-397. [CrossRef]

34. Hutchings, M.J.; John, E.A.; Wijesinghe, D.K. Toward understanding the consequences of soil heterogeneity for plant populations and communities. Ecology 2003, 84, 2322-2334. [CrossRef]

35. Tälle, M.; Deák, B.; Poschlod, P.; Valkó, O.; Westerberg, L.; Milberg, P. Grazing vs. mowing: A meta-analysis of biodiversity benefits for grassland management. Agric. Ecosyst. Environ. 2016, 222, 200-212. [CrossRef]

36. Oenema, O.; Velthof, G.L.; Yamulki, S.; Jarvis, S.C. Nitrous oxide emissions from grazed grassland. Soil Use Manag. 1997, 13, 288-295. [CrossRef] 
37. Di, H.; Cameron, K. Nitrate leaching in temperate agroecosystems: Sources, factors and mitigating strategies. Nutr. Cycl. Agroecosyst. 2002, 64, 237-256. [CrossRef]

38. Orwin, K.H.; Bertram, J.E.; Clough, T.J.; Condron, L.M.; Sherlock, R.R.; O'Callaghan, M. Short-term consequences of spatial heterogeneity in soil nitrogen concentrations caused by urine patches of different sizes. Appl. Soil Ecol. 2009, 42, 271-278. [CrossRef]

39. White-Leech, R.; Liu, K.; Sollenberger, L.E.; Woodard, K.R.; Interrante, S.M. Excreta deposition on grassland patches. II. Spatial pattern and duration of forage responses. Crop Sci. 2013, 53, 696-703. [CrossRef]

40. Peng, J.; Wang, Y.; Zhang, Y.; Wu, J.; Li, W.; Li, Y. Evaluating the effectiveness of landscape metrics in quantifying spatial patterns. Ecol. Indic. 2016, 10, 217-223. [CrossRef]

41. Shepherd, M.J.; Anderson, J.M.; Bol, R.; Allen, D.K. Incorporation of ${ }^{15} \mathrm{~N}$ from spiked cattle dung pats into soil under two moorland plant communities. Rapid Commun. Mass. Spectrom. 2000, 14, 1361-1367. [CrossRef]

42. White, S.L.; Sheffield, R.E.; Washburn, S.P.; King, L.D.; Green, J.T., Jr. Spatial and time distribution of dairy cattle excreta in an intensive pasture system. J. Environ. Qual. 2001, 30, 2180-2187. [CrossRef]

43. Michelena, P.; Sibbald, A.M.; Erhard, H.W.; McLeod, J.E. Effects of group size and personality on social foraging: The distribution of sheep across patches. Behav. Ecol. 2009, 20, 145-152. [CrossRef]

44. Huang, Y.; Wang, L.; Wang, D.; Li, Y.; Alves, D.G. The effect of plant spatial pattern within a patch on foraging selectivity of grazing sheep. Landsc. Ecol. 2012, 27, 911-919. [CrossRef]

45. Getzin, S.; Yizhaq, H.; Cramer, M.D.; Tschinkel, W.R. Contrasting global patterns of spatially periodic fairy circles and regular insect nests in drylands. J. Geophys. Res. Biogeosci. 2019, 124, 3327-3342. [CrossRef]

46. Gillet, F.; Kohler, F.; Vandenberghe, C.; Buttler, A. Effect of dung deposition on small-scale patch structure and seasonal vegetation dynamics in mountain pastures. Agric. Ecosyst. Environ. 2010, 135, 34-41. [CrossRef]

47. Scheile, T.; Isselstein, J.; Tonn, B. Herbage biomass and uptake under low-input grazing as affected by cattle and sheep excrement patches. Nutr. Cycl. Agroecosyst. 2018, 112, 277-289. [CrossRef]

48. Xi, N.; Carrère, P.; Bloor, J.M.G. Nitrogen form and spatial pattern promote asynchrony in plant and soil responses to nitrogen inputs in a temperate grassland. Soil Biol. Biochem. 2014, 71, 40-47. [CrossRef]

(C) 2020 by the authors. Licensee MDPI, Basel, Switzerland. This article is an open access article distributed under the terms and conditions of the Creative Commons Attribution (CC BY) license (http://creativecommons.org/licenses/by/4.0/). 